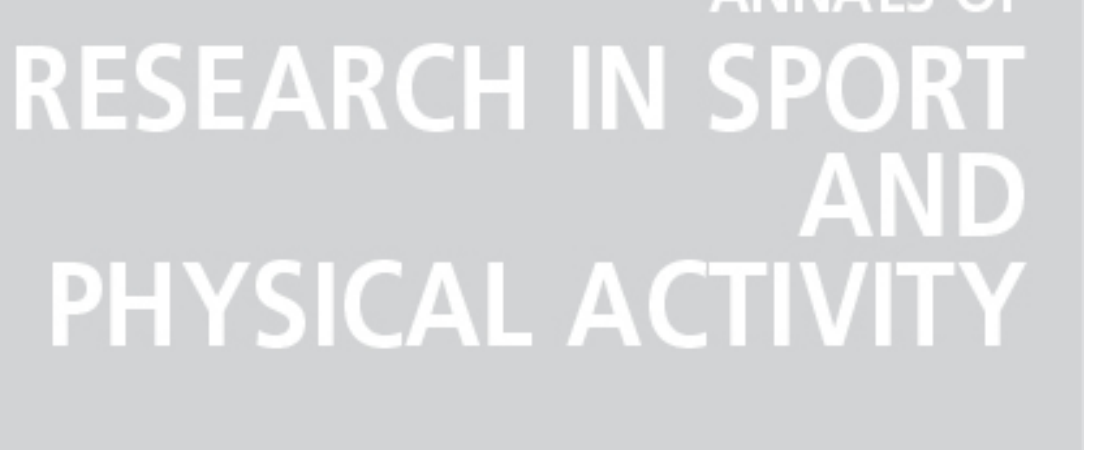

\title{
Profiling skeletal muscle injury and regeneration using proteomics
}

Autor(es): $\quad$ Peake, Jonathan; Liu, Lian; Parker, Tony; Broszczak, Daniel

Publicado por: Imprensa da Universidade de Coimbra

URL

persistente: URI:http://hdl.handle.net/10316.2/44072

DOI: DOl:https://doi.org/10.14195/2182-7087_ex2018_9

Accessed : $\quad$ 26-Apr-2023 13:09:48

A navegação consulta e descarregamento dos títulos inseridos nas Bibliotecas Digitais UC Digitalis, UC Pombalina e UC Impactum, pressupõem a aceitação plena e sem reservas dos Termos e Condições de Uso destas Bibliotecas Digitais, disponíveis em https://digitalis.uc.pt/pt-pt/termos.

Conforme exposto nos referidos Termos e Condições de Uso, o descarregamento de títulos de acesso restrito requer uma licença válida de autorização devendo o utilizador aceder ao(s) documento(s) a partir de um endereço de IP da instituição detentora da supramencionada licença.

Ao utilizador é apenas permitido o descarregamento para uso pessoal, pelo que o emprego do(s) título(s) descarregado(s) para outro fim, designadamente comercial, carece de autorização do respetivo autor ou editor da obra.

Na medida em que todas as obras da UC Digitalis se encontram protegidas pelo Código do Direito de Autor e Direitos Conexos e demais legislação aplicável, toda a cópia, parcial ou total, deste documento, nos casos em que é legalmente admitida, deverá conter ou fazer-se acompanhar por este aviso. 


\section{ANNALS OF RESEARCH IN SPORT AND PHYSICAL ACTIVITY}




\title{
PROFILING SKELETAL MUSCLE INJURY AND REGENERATION USING PROTEOMICS
}

\author{
Jonathan Peake1, Lian Liu'1 , Tony Parker ${ }^{1}$, Daniel Broszczak ${ }^{1,2}$
}

KEY WORDS: muscle injury, inflammation, necrosis, regeneration, proteome signature, network analysis

Muscle contusion injuries are relatively common in contact sports, workplace and vehicular accidents. They are associated with significant acute necrosis and inflammation, followed by regeneration over 2-4 weeks. Muscle contusion injuries have been characterised using histology, immunohistochemistry and some molecular techniques. However, few studies have employed global proteomics profiling to investigate the time course of changes in the protein composition of muscle in the different phases of tissue destruction, repair and remodelling. Mass spectrometry based proteomics offers some key analytical benefits, including the ability to catalogue a large number of proteins and establish comprehensive biomarker signatures that represent important physiological processes. We induced muscle contusion injury in anaesthetised rats by dropping a cylindrical $400 \mathrm{~g}$ weight on the hind limb, in the region of the gastrocnemius muscle. The rats were then allowed to recover for $6 h, 12 h, 1,3,7$ or $14 d$ before they were sacrificed ( $n=5$ per time point). A control group of $n=5$ non-injured animals was also included. The gastrocnemius was removed and snap frozen in liquid N2. Around $50 \mathrm{mg}$ of muscle tissue were dissected and placed in a microcentrifuge tube for homogenisation, sonication and protein extraction. Samples were centrifuged to collect the supernatant, and the protein concentration was measured. A pooled sample prepared with muscle from all of the animals was divided in two and fractionated by LDS-PAGE and OFFGel electrophoresis. Subsequent fractions were digested using in-gel digestion or the filter-aided sample preparation (FASP) technique, respectively. All 35 individual samples were digested by FASP. Liquid chromatography tandem mass spectrometry (LC-MS/MS) analysis was performed. Fractions of pooled samples were

\footnotetext{
1 Tissue Repair and Translational Physiology Program, School of Biomedical Sciences and Institute of Health and Biomedical Innovation, Queensland University of Technology, Brisbane, Australia;

2 School of Science, Faculty of Health Sciences, Australian Catholic University, Brisbane, Australia
} 
analysed by data-dependent acquisition, whereas each individual sample was analysed by data-independent acquisition. A peptide-spectrum identification search using a UniProt rat database was performed on all the data from fractionated samples through ProteinPilot software, which identified around 2,000 different proteins in the muscle homogenates. The over-represented biological processes, molecular functions, and cellular components were determined through Gene Ontology (GO) enrichment analysis of the whole muscle proteome, using the BiNGO app within Cytoscape (Version 3.4.0). The top biological processes included cellular metabolic processes, catabolic processes, translational elongation, electron transport chain, oxidation/reduction and cellular respiration. The top molecular functions included protein binding, catalytic activity, oxidoreductase activity, translation factor activity, nucleotide binding and hydrolase activity. The top cellular components included the cytoplasm, cytosol, mitochondrion, organelle and protein complex. Data analysis is ongoing to establish a temporal profile of quantitative changes in biological processes, molecular functions and cellular components during the phases of muscle tissue destruction, repair and regeneration. 